
\title{
28 Research Square \\ Identification of Groundwater Potential Zones using Geospatial Techniques in Palar River Basin, Tamil Nadu, India
}

MANJUNATHAN NARAYANAN ( $\nabla$ earthmanjunath@gmail.com )

Government Arts College (Autonomous), Salem https://orcid.org/0000-0001-9478-8465

THIRUKUMARAN VENUGOPAL

Government Arts College (Autonomous) Salem

\section{Research Article}

Keywords: Rainfall, Water Level, Theissen Polygon, ARIMA, ArcGIS, Groundwater Potential Zone.

Posted Date: August 17th, 2021

DOI: https://doi.org/10.21203/rs.3.rs-625147/v1

License: (ㅇ) (i) This work is licensed under a Creative Commons Attribution 4.0 International License. Read Full License 


\section{Abstract}

The present research work is aimed to identify the groundwater potential zones in the Palar River Basin (PRB). The Auto Regressive Integrated Moving Average (ARIMA) model, and geospatial techniques were used to determine the Groundwater Potential Zone (GPZ). Time series analysis is commonly used in a broad range of scientific applications including hydrology, metrology, geo-statistics, engineering and environmental management fields. The geospatial historical data of rainfall and water level recorded at yearly intervals for 14 years (2005 to 2018) was used to identify the fluctuation of water level with respect to rainfall with lower and upper confidence levels and eventually leads to identify the spatial variation of the groundwater potential zones. The ARIMA model evolved from analysis was further classified into Four types of goodness of fits namely excellent fit, good fit, poor fit, and no fit. The spatial variation of groundwater potential occurrence and behaviour of the region is controlled by geology, lineament, geomorphology and drainage. These layers have been integrated with the ArcGIS platform for generating Groundwater Potential Zone (GPZ) maps. The validation of the result shows that Excellent fits 40 wells (12.82\%), good fits 108 wells (34.62\%), poor fits 58 wells $(16.66 \%)$, and no fits 106 wells (33.97\%), the study area good groundwater potential zones approximately $47.44 \%$. This research suggests that a good groundwater potential zone occurs in patches of the southern and eastern parts of the study area.

\section{Introduction}

Groundwater is one of the most important natural resources and mainly utilizing for Domestic (Drinking), Irrigation and Industrial purpose (Agarwal and Garg, 2016). Rainfall is the main source of groundwater and other surface water resources. Hence, it plays a fundamental role in human health, economic development and ecological diversity (IPCC, 2001). There is a progressive increase in groundwater utilization with an advancement of technology and a continual increase in the industrial, population, irrigation every year (Mondal and Dalai, 2017; CGWB, 2017). At present, groundwater contributes $36 \%$ for domestic, $42 \%$ for agricultural, and $27 \%$ for industrial purposes (Taylor et al., 2013a, b). In the past decade, water demand was more impressive than ever before, due to climate change and human development activities (Shah, 2005; Taweesin et al., 2018). However, water scarcity is expected to be the biggest challenge in the 21st century (Garg and Hassan, 2007).

So far, number of research works have been carried out in minor and major levels in the subject of Groundwater Potential Zone. Assessment of Groundwater Potential zones (Senthil Kumar and Shankar, 2014; Anjali Singh et al., 2015; Gumma and Pavelic, 2013; Chenini et al., 2010; Vanessa Madrucci et al., 2008) have widely applied in GIS techniques. The delineation of groundwater potential zone various factors such as lineament, fault, fractures, shear zones and hydro-geo-structural (Jasrotia et al., 2007; Biswas Arkoprovo et al., 2012; Nag, 2005; Javed Mallick et al., 2015; Kamal Taheri et al., 2016), morphology, drainage system, paleochannels, structural occurrence and texture (Magesh et al., 2011; Rajaveni et al., 2017; Thomas, 2011; Vaidyanadhan, 1971; Rasmi et al., 2016; Thirumurugan, 2016) and geochemical analysis (Kanagaraj et al., 2018), geospatial technique, groundwater recharge (Dabral et al, 2013). There are various geostatistical methods were adopted to identify the groundwater potential zone, such as Theissen Polygon method was used to derive the rainfall distribution map, based on the rainfall and water level (Ragunath, 1986; Jaya Rami Reddy, 2001; Singh, 1992; Vassan, 2002; Preeja et al., 2011) Box - Jenkins ARIMA model Identification, Estimation and Diagnostic checking (Box and Jenkins et al., 2015; Thirumurugan, 2016; Manjunathan et al., 2021; Pankratz, 1983; Sharma, 1995; Chambers et 
al., 1983). Many of the existing studies have widely applied ArcGIS techniques for identifying the GPZ (Krishnamurthy et al., 1996; Srivastava and Bhattacharya, 2006). Whereas, identification of groundwater potential zone for whole Palar River Basin not yet taken forward. Therefore, this research attempted little attention with respect to groundwater potential zone identification in the PRB.

The study area eastern part of costal belt benefits northeast monsoon and western part of western-ghats benefits south-west monsoon an intermediate plateau benefit poor rainfall in both monsoon season. The groundwater occurrence in central, northern and western are highly dynamic and the fluctuation is high, where it is controlled by rainfall recharge during monsoons. The basin receives its major rainfall share during the northeast and southwest monsoon while remains comparatively very less in another season. Although in the central part of the study area is a chronically drought-prone area (CGWB, 2008).

Geology/Lithology plays an important role in the occurrence and distribution of groundwater since it is the controlling factor of infiltration factor. In the crystalline formation primary porosity almost absent or low, only secondary porosity and permeability are present (Balamurugan et al., 2008). In the sedimentary rocks alluvial deposits having better porosity and permeability (Seifu Kebede, 2013).

The present study focuses on the identification of groundwater potential zones in the palar river basin, based on two variables rainfall (independent) and water level (dependent), using the Thissen Polygon method, ARIMA model, ArcGIS techniques, involves interpretation of various themes such as lithology, lineament, geomorphology drainage, etc. which have been used in inferring the occurrence of groundwater.

Theissen polygon segments (Rainfall and Water Level) for the individual locations interpolated into ARIMA modelling were computed using SPSS software. The software involves various preparatory steps for computation of model i.e., identification, estimation and diagnostic checking, these three stages were applied to determine the Upper Confidence Level (UCL m bgl), Lower Confidence Level (LCL m bgl) and the Mean Water Level (MWL $\mathrm{m} \mathrm{bgl}$ ). Thus, results are interpolated into the ArcGIS platform and goodness of fit overlayed on various geological and geomorphological factors which is four thematic layers opted in this study includes geology/lithology, lineament, geomorphology, drainage, with the help of these results finally identified groundwater potential zones.

\section{Study Area}

Palar River Basin is one of the 17 major river basins in Tamil Nadu. The main palar river is alias a milk river, it originates from Nandi Durga, Chikkaballapura district in the eastern part of Karnataka state and at an altitude of $1428 \mathrm{~m}$ AMSL. The river flows downstream, passes through the small distance of Kolar goldfield and enters into the west of Kollapalli village, Vaniyambadi town, Vellore district, Tamil Nadu and finally mix with the Bay of Bengal. The study area is located (Fig. 1), between latitude $12^{0} 36^{\prime} 26^{\prime \prime}$ to $12^{0} 31^{\prime} 26^{\prime \prime}$ North and longitude $78^{\circ} 24^{\prime} 43^{\prime \prime}$ to $80^{\circ} 09^{\prime} 54^{\prime \prime}$ and palar river basin geographical area is $17,663.19 \mathrm{sq}$. km which includes an area of 3,123 sq. km in Karnataka state, 4,267 sq. km in Andhra Pradesh and 10,273.19 sq. km in Tamil Nadu. The total river length about 348 km, 222 km in Tamil Nadu, 33 km in Andhra Pradesh and 93 km in Karnataka (Fig. 1). The Basin is divided into three major topographical divisions namely, (i) the high land region comprising the Eastern Ghats hill range with elevation varying from $1428 \mathrm{~m}$ to $300 \mathrm{~m}$ represented mostly with a rolling topography of high relief to low relief, (ii) the plateau region with elevation ranging between $300 \mathrm{~m}$ to $150 \mathrm{~m}$, 
which comprise the relict relief valleys etc, and (iii) the lowland zone of coastal plains with an elevation variation from $150 \mathrm{~m}$ to $1 \mathrm{~m}$, with a low relief to gentle slope towards the coastal zone (Narasimhan, 1990). All the major rivers are originating from western ghats and flow towards eastwards, which is Palar, Ponnaiyar, Cheyyar, Kortallaiyar, Araniyar and minor intermediates' tributaries are joining into Palar River which is Poineyar, Kavundinya-nadhi, Goddar, Malattar, Cheyyar, Agaramar, Kamandalar, Naganadhiyar, Killiyar and Vegavathiyar.

The palar river basin within Tamil Nadu covers Tiruvallur, Kanchipuram, Vellore and Tiruvannamalai districts [These districts further subdivided into Kanchipuram district divided into Kanchipuram and Chengalpattu, Vellore district trifurcated into Vellore, Tirupathur and Ranipet]. Even though, study area majorly covers three districts namely Kanchipuram, Vellore and Tiruvannamalai.

\section{Materials And Methodology}

The methodology adopted for the present study is shown in Fig. 2. The primary and secondary data sources were used to identify the groundwater potential zones. Primary data source which is a detailed field investigation was carried out to check the accuracy of visual interpretation and also to map the locations of wells (Monitoring wells, Irrigation wells, Dug wells and public wells) for the entire palar basin. The secondary data source of rainfall (40 Rainfall stations) and water level (312 water level stations) on yearly basis for the period 14 years (2005-2018) were collected from Groundwater Resources Data Centre, PWD department, Tamil Nadu.

Geospatial distribution map was generated by using the Theissen polygon method. It is one of the widely used techniques and important method, it gives better accuracy and satisfactory results. Thiessen polygon most frequently used deterministic methods which are Nearest Neighbouring (NN) and Inverse Distance Weighting (IDW) (Thiessen, 1991). Theissen polygon method NN is adopted to study the rainfall versus water levels (Fig. 3). The Thiessen Polygon method assumes that the rainfall is observed values and the water level is dependant values. These polygons are formed by the mediators of segments joining into nearby stations (rainfall station) to other related stations (water level stations). The polygon must be changed every time a station is added or deleted from the network (Thiessen, 1991). This method is more suitable for the mountainous region because of the orography of the rain (Ragunath, 1986).

The time series ARIMA model has been commonly used in a broad range of scientific applications, including hydrology, hydro-metrology and geo-statistics; however, applications for drought forecasting have been limited (Mishra and Singh, 2010; Brockwell and Devis, 1991). The time series ARIMA model is a valuable tool to obtain information with an analysable data structure with all its intrinsic components (Haan, 1977; Pankratz, 1983; Box and Jenkins et al., 2015). Some of the major advantages of time series models include their systematic search capability for identification, estimation and diagnostic checking (Sharma, 1995). Time series ARIMA models effectively consider linear regression and correlation (Box and Jenkins et al., 2015). The linear regression least square methods were computed from the time series ARIMA model; thus, results are integrated into the ArcGIS platform to identify the groundwater potential zones.

\subsection{Model Identification or Checking}


The model identification of first stage is to determine the stationarity and significance of the seasonality. The ARIMA model is computed using the P, D, Q parameters (Aflatooni and Mardaneh, 2011). The higher order of auto regressive plots is substantiated by the auto correlation plots and partial auto correlation plots where they should have minimal outliers and the decay of the spikes should be minimal (Chitra et al., 2015). The determination of $95 \%$ confidence intervals of the ACF and PACF plots confirm the character of the model generated by the (P D Q) ARIMA model, the BIC as information-based criteria to substantiate the validation of the model (Pankratz, 1983).

\subsection{Model Estimation}

The best fit model estimation was computed in maintaining the model statistics at the minimum for the Bayesian Information Criterion (BIC), the most commonly used function is BIC $(p, q)=\ln \sigma^{\wedge} 2^{\frac{(p+q) \ln (n)}{n}}$, where ( $\sigma^{\wedge} 2$ is a sample covariance function), and maximum for the $R^{2}$ parameter. Also, the testing of the model for its computational correctness was done using $t$ statistic and test of significance have confirmed by derivation of the best fit ARIMA model (Chitra et al., 2015; Mohamed and Ibrahim, 2016).

\subsection{Diagnostics Checking}

The diagnostics checking is the last (Third) stage to validate the ARIMA model. The maintenance of minimum $\mathrm{BIC}$ values and the confidence levels of the models were maintained at the minimum for the entire 312 wells (water level stations) ARIMA model derived for the study area. The Auto correlation of the residuals and the BoxLjung Q (1978) statistic computed were also at minimum diagnosis of the best fist models. The maintenance of the significance levels testing done for the model, also revealed the computation of the goodness of fit or best fit model. ARIMA models of all the locations show a minimum Box-Ljung Q statistic computed for the ARIMA models with confidence levels of $95 \%$. The outliers of the ACF and PACF plots and the models are well maintained to be below or near zero confirming the valid diagnostic character of the model (Box and Jenkins et al., 2015). All the models derived have smaller BIC values and the maximum R2 and the stationary residual error values. Thus, the ARIMA model diagnosis of the palar basin revealed the best-fitting model for the entire study locations with a minimum BIC value.

\subsection{Linear Regression Analysis}

The computed ARIMA model for 40 rainfall stations and 312 water level well locations of UCL, LCL and MWL were elucidated. The identified MWL of all the individual water well (water levels) locations were further statistically treated for their relationship of goodness of fit (Chambers et al., 1983), with the Linear Regression Analysis method involving the method of Least Square technique (Sharma, 1995).

Linear Regression analysis methods are used to analyse the bivariate data set, where one variable can function on another. Rainfall is the independent variable and water level is the dependent variable.

\section{a. Regression of $Y$ on $X$ \\ b. Regression of $X$ on $Y$}

The line of regression $Y$ on $X$ or $X$ on $Y$ is in the algebraic form $Y=a+b X$ or $X=a+b Y$ respectively where $Y$ is the dependent variable on the independent variable $X . a$ and $b$ is the algebraic normal equation (Sharma, 1995). 
Normal equation $\sum \mathrm{y}=\mathrm{na}+\mathrm{b} \sum \mathrm{x}$

$$
\sum x y=a \sum x+b \sum x 2
$$

Least square equation by $\quad \mathrm{x}=\frac{\mathrm{n} \sum \mathrm{dxdy}-\left(\sum \mathrm{dx}\right)\left(\sum \mathrm{dy}\right)}{\mathrm{n} \sum \mathrm{dx}^{2}-\left(\sum \mathrm{dx}\right)^{2}}$

$$
b x y=\frac{\mathrm{n} \sum \mathrm{dxdy}-\left(\sum \mathrm{dx}\right)\left(\sum \mathrm{dy}\right)}{\mathrm{n} \sum \mathrm{dy}^{2}-\left(\sum \mathrm{dy}\right)^{2}}
$$

The regression line $Y$ on $X$ is used to estimate and predict the best value in the least square sense for a given value of $X$, where $Y$ is dependent on $X$. The fitting on a straight line is to illustrate the linear regression line by the least square's method (Sharma, 1995). The values of $a$ and $b$ are substituted in the normal equation $Y=a+$ $b X$ or $X=a+b Y$ to get thegoodness of fit in the least square sense, the trend is an excellent fit, good fit, poor fit and no fit.

\section{Results And Discussion}

Groundwater potential availability mainly depends upon rainfall, geology, lineament, geomorphology and drainage. The ARIMA model derived MWL (m) bgl, UCL (M) bgl and LCL (m) bgl and its goodness of fit of Excellent fit, Good fit, Poor fit and No fit results are interpolated in ArcGIS platform and extrapolated various thematic maps pertaining to the study area.

\subsection{Rainfall}

Rainfall is the primary source of groundwater recharge where water is infiltrated by fractures into the subsurface. The amount and Spatio-temporal distribution of rainfall highly influenced in hydrology and hydrogeological condition. Although, rainfall intensity and combine with other favourable conditions helps to identify the GPZ. The groundwater possibility, groundwater is high if the rainfall is high and groundwater is low if the rainfall is low.

Tamil Nadu state rainfall mainly receives in three seasons i.e., pre-monsoon, southwest monsoon and postmonsoon seasons. This season's maximum rainfall is $1395 \mathrm{~mm}$ and minimum rainfall is $460 \mathrm{~mm}$ and average annual rainfall is $958 \mathrm{~mm}$. About $50 \%$ of the total annual average rainfall is received during the northeast monsoon, therewith about $31 \%$ is received during the southeast monsoon and the balance in other seasons. With respect to the above, coastal districts receive about $65-75 \%$ of annual rainfall and interior districts receive about $25-35 \%$ in all seasons. The rainfall distribution is not constant in all-season having inter-seasonal variability due to the non-formation of rain causing mechanisms.

The palar river basin have experience significant seasonal variation in rainfall (Fig. 4). However, the basin receives more rainfall during the northeast (NEM) monsoon (October to November), maximum rainfall is 45-65 $\%$ and during the south-west (SWM) monsoon (June to September), receives nearly 30 to $40 \%$ and the remaining 25-35\% of rainfall receives in winter seasons (January and February) and summer seasons (March to May) (CGWB, 2008). The palar river basin eastern part (particularly the coastal belt) is a subtropical climate, dominant precipitation, its comparatively experiences more rainfall from the northeast (NE) monsoon. The western part of the study area receives a sustainable amount of rainfall intermediate portion of the study area receives occasional spells of northeast, northwest and southwest monsoonal rains. 


\subsection{Geology}

The study area groundwater potentiality is depending on porosity and permeability, namely rocks occurrences of the region. Groundwater occurs in hard rock formations which is crystalline, gneissic rocks (Hornblende gneiss, Hornblende-Biotite gneiss, Granotide gneiss, Tholetic, Komatiitic affinity and Migmattic gneiss) are in upper reaches and Charnockites are present in the middle reaches, considered as less to moderate groundwater potential zone and soft rocks formations which is alluvial, fluvial deposits (sandstone, silt, clay, fossiliferous shale, conglomerate, alluvium and gravels) are considered as a good groundwater potential zone (Rajaveni et al., 2017; Madrucci et al., 2008; Balakrishnan and Rajamani, 1987; Subba Rao, 2006). The different lithological units were demarcated and delineated on the basis of a published geology map (GSI, 2005) and oriented with Tamil Nadu Geology map (GSI, 2016) and also necessary field checks were carried out (Fig. 5). However, Charnockite are present in the middle reaches of the Palar River and after Arcot, the river drains the recent alluvium and lower Gondwana formation followed by Granulates terrain Archean formation and lastly, the costal alluvium having no interconnected porous hence can neither absorb nor transmit water, these rocks porosity almost absent (Narasimhan, 1990). Groundwater occurs in the sedimentary formation which is sandstone, silt, clay, fossiliferous shale, conglomerate, alluvium and gravels having less porosity and high permeability, hence can transmit water, these rocks porosity present (Tiwari and Rai, 1996; Seifu Kebede, 2013). All sedimentary rocks, especially alluvial deposits are having good potential because they are recent deposits and have better permeability. Although, palar river basin groundwater occurs mostly underwater table or phreatic (semi-confined) conditions.

\subsection{Lineament}

The Lineaments are controlling the groundwater infiltration and act as a transmitting medium, especially in fractured hard rock terrain (Thirukumaran et al., 2014; Balamurugan et al., 2008). Lineaments are straight, long, linear features by the permeability of the terrain, which is developed by tectonic activity. In the study area, around $80 \%$ of lineaments are fault, shear zones and dykes, these structural features might affect groundwater flow. However, low lineament areas indicate a low infiltration rate and high lineament areas indicate a high infiltration rate (Gupta and Srivastava, 2010). The study area lineaments are aligned in N-S, E-W, NW-SE, NE-SW, NNW-SSE and WNW-ESE direction. Most of the lineaments are in the northern, western and southern parts of the study area (Fig. 6). Therewith, some of the lineaments are very old being Precambrian Eon (Jurasic to quarternary).

\subsection{Geomorphology}

Geomorphology plays a vital role in the occurrence of groundwater (Fig. 7). Geomorphological features help to identify various landforms such as structural hills, denudational hills, residual hills, pediments (Ramasamy and Anbazhagan, 1997; Balamurugan et al., 2008). The structural hills, denudational hills, residual hills, which are structurally controlled with or without complex folding and faulting, have a gentle slope with medium vegetation cover and fissures. Pediments are gently sloping smooth surface or erosional bedrock with thin detritus, where it has more runoff and poor groundwater potential. Pedplain is widely found to occur in the recharge region having gentle steepness with wide vegetation and rich in groundwater potential. Alluvial plains land is an extensive deposition of alluvium, usually adjacent to the river that periodically overflows its banks. 
The major part of the area is characterized by an undulating topography with innumerable local depressions and having moderate to good groundwater occurrence.

\subsection{Drainage}

Drainage carries water from the mountain region to plain, it plays a major role as the groundwater source in the region. The drainage systems are controlled by structural features like faults and fractures in the area, low drainage patterns are indicating comparatively higher infiltration and low runoff, very high or closeness of drainage patterns indicating a low infiltration and high runoff (Rasmi et al., 2016). Actually, regions with low drainage permit more infiltration of surface flow into the groundwater recharge and high drainage permits less infiltration of wasted as the surface flows into less groundwater recharge (Gupta, et al., 1994). The drainage characteristics in the study area (Fig. 8) complicated with its history of constant changes in the course of major streams. Most of the rivers through perennials have very little flow for the major part of the year, especially during the dry season. During the monsoon, however, these rivers inundate areas.

\section{Groundwater Potential Zone mapping}

In this study, the groundwater potential zone was derived by integration of all thematic layers using the goodness of fit calculation into ArcGIS. The groundwater potential zone map prepared by this below shown method (Fig. 9). The study area was classified into four classes with groundwater potentiality, such as 1 is Excellent, 2 is Good, 3 is Poor, 4 is no or very less.

$\mathrm{GPZ}=\sum$ Excellent Fit (Geology + Lineament + Geomorphology + Drainage + Good Fit (Geology + Lineament + Geomorphology + Drainage) + Poor Fit (Geology + Lineament + Geomorphology + Drainage) + No Fit (Geology + Lineament + Geomorphology + Drainage)

The low potential region is found in the northern and western region of the study area which is covered by hilly terrain, occupied by weathered rocks, structural hills and their lineament transforming the water is less and high potential is found in southern and southeast parts of the study area which are plane area, irrigation lands, sedimentary terrain where the infiltration is high. The study area result found that Excellent fit 40 wells (12.82\%), good fits 108 wells (34.62\%), poor fits 58 wells (16.66\%) and very less or no fits 106 wells (33.97\%) and \%), the study area good groundwater potential zones approximately $47.44 \%$. Thus, finding the groundwater potential helps in accurate zones for exploitation for agricultural, industrial and domestic purposes.

\section{Conclusion}

Based on this study area research. It is concluded for the entire study area is indicating the results of excellent, good, poor, very less or no groundwater zones. Within this Excellent fit 40 wells (12.82\%), Good fits 108 wells $(34.62 \%)$ are indicating groundwater potential zone and Poor fits 58 wells $(16.66 \%)$ are indicating medium groundwater potential zones and very less or No fits 106 wells (33.97\%) are indicating very less groundwater potential zones. The study area encompassing of good Groundwater Potential Zones (GPZ) is 47.44\%. Further, it has been observed that northwest and central part sensitive region drought prone area water level was declined due to orogeny of the region. 
Further, the outcome of the research result will helpful to first-hand information planners and government agencies for sustainable utilization of groundwater.

\section{Declarations}

\section{Acknowledgments}

The author is highly indebted to all secondary data provider organization. The author is also grateful to those individuals who assist in different stages of this work.

\section{Compliance with Ethical Standards}

This study was in "Compliance with Ethical Standards". "For this type of study formal consent is not required."

\section{Consent to participate}

“Not applicable", This study declaring that no prisoners, organs/tissues were not involved.

\section{Consent to publish}

“Not applicable", This study manuscript does not contain data from any individual person.

\section{Ethical Conduct}

"This chapter does not contain any studies with human participants or animals performed by any of the authors." "Informed consent was obtained from all individual participants included in the study."

\section{Funding}

This study was not funded by any agencies.

\section{Competing interests}

The authors declare that they have no competing interests

\section{Authors' Contributions}

Manjunathan Narayanan has conceived of the study, participated in the formulating design, coordinated the conduct of the study including data collection, assisted in interpreting the data, performed the statistical analysis and interpreted the data; Thirukumaran Venugopal has participated in the design of the study, assisted in interpreting the data, and helped to draft the manuscript. Both the authors read and approved the final manuscript.

\section{Availability of data and materials}

The datasets generated and/or analysed during the current study are not publicly available due to Authors Ph.D. research work, but are available from the corresponding author on reasonable request. 


\section{References}

1. Agarwal Rajat, Garg, P.K., 2016. Remote Sensing and GIS Based Groundwater Potential \& Recharge Zone Mapping Using Multi-Criteria Decision Making Technique, Water Resources Management, Volume 30, Issue 1, 243-260. DOI: 10.1007/s11269-015-1159-8

2. Anjali Singh, S.K., Srivastav, Sudhir Kumar, Govind J. Chakrapani, 2015. A modified-DRASTIC model (DRASTICA) for assessment of groundwater vulnerability to pollution in an urbanized environment in Lucknow, India, Environmental Earth Science, 74, 5475-5490, DOI:10.1007/s12665-015-4558-5.

3. Balakrishnan, S., Rajamani, V., 1987. Geochemistry and petrogenesis of granitoids around the kolar schist belt, South India: Constraints for the evolution of the crust in the kolar area, The Journal of Geology, Volume 9, Issue 2. https://doi.org/10.1086/629121

4. Balamurugan, G., Anbazhagan, S., Biswal, T.K., 2008. Remote sensing for delineating deep aquifer zones, Hosur-Rayakottai region, India. National Symposium on Advances in Remote Sensing Technology and Applications with Spatial Emphasis on Microwave Remote Sensing and Annual Convention of Indian Society of Remote Sensing (ISRS), Ahmedabad, Gujarat, India, December 18-20, 2008.

5. Biswas Arkoprovo, Jana Adarsa, Sharma Shashi Prakash, 2012. Delineation of Groundwater Potential Zones using Satellite Remote Sensing and Geographic Information System Techniques: A case study from Ganjam district, Orissa, India, Research Journal of Recent Sciences, Volume 1, Issue 9, 59-66. Available online at: www.isca.in

6. Brockwell Peter, J., Davis Richard, A., 1991. Time Series; Theory and method, second edition, Springer Series in Statistics, Springer, New York. https://doi.org/10.1007/978-1-4419-0320-4

7. Central Groundwater Board (CGWB), 2008. A $21^{\text {st }}$ Century Institutional Architecture for Indian's Water Reforms, Report submitted by the Committee on Restructuring the CWC and CGWB. Retrieved from: http://cgwb.gov.in/INTRA-CGWB/Circulars/Report_on_Restructuring_CWC_CGWB.pdf

8. Central Groundwater Board (CGWB), 2017. National Compilation on Dynamic Ground Water Resources of India, Central Ground Water Board Department of Water Resources, RD \& GR Ministry of Jal Shakti Government of India Faridabad. Retrieved from http://cgwb.gov.in/Documents/Dynamic-GW-Resources2011.pdf

9. Chambers John, M., William Cleveland, S., Beat Kleiner, Paul Tukey, A., 1983. Graphical Methods for Data Analysis, $1^{\text {st }}$ edition, Chapman and Hall/CRC. https://doi.org/10.1201/9781351072304.

10. Chenini Ismail, Abdallah Ben Mammou, Moufida El May, 2010. Groundwater Recharge Zone Mapping Using GIS-Based Multi-criteria analysis: a case study in Central Tunisia (Maknassy Basin), Water Resources Management, 24, 921-939.

11. Chitra, N., Shanmathi, R., Rajesh, R., 2015. Application of ARIMA model using SPSS software - A case study in supply chain management, International Journal of Science, Technology \& Management, Volume 4, Special issue 01, 206-215.

12. Dabral Sumit, Sharma, N., Bhatt Bindu, Joshi Janak, P., 2013. A geospatial technique for demarcating ground water recharge potential zones: A study of Mahi-Narmada Inter stream region, Gujarat, International Journal of Geomatics and Geosciences, Volume 4, Issue 1, 177-185.

https://www.indianjournals.com/ijor.aspx?target=ijor:ijggs\&volume=4\&issue=1\&article=016 
13. Garg, N.K., Hassan, Q., 2007. Alarming scarcity of water in India, Current Science, Volume 93, Issue 7, 932941. Https://www.jstor.org/stable/24099258.

14. Geological Survey of India (GSI), 2005, 2016. Geological map of Tamil Nadu.

15. George, E. P., Box, Gwilym, M., Jenkins, Gregory, C., Reinsel, Greta, M., Ljung, 2015. Time Series Analysis: Forecasting and Control, Fifth edition, Wiley Publication, United Kingdom. https://www.wiley.com/enin/Time+Series+Analysis:+Forecasting+and+Control,+5th+Edition-p-9781118675021

16. Gumma Murali Krishna, Pavelic Paul, 2013. Mapping of Groundwater Potential Zones across Ghana using remote sensing geographic information system, and spatial modelling, Environmental Monitoring and Assessment, 185, 3561-3579.

17. Gupta Manika, Srivastava Prashant, K., 2010. Integrating GIS and remote sensing for identification of groundwater potential zones in the hilly terrain of Pavagarh, Gujarat, India, Water International, Volume 35, Issue 2, 233-245.

18. Gupta, C. P., Thangarajan, M., Rao, V. V. S. G., Ramachandra, Y. M., Sarma, M. R. K., 1994. Preliminary study of groundwater pollution in the upper Palar Basin and feasibility of mass transport modelling to predict pollutant migration, National Geophysical Research Institute (NGRI), Hyderabad, Technical Report No, 94 GW-168.

19. Haan, C.T., 1977. Statistical Methods in Hydrology, first edition, Ames: lowa State University Press, lowa, 378-391. https://www.worldcat.org/title/statistical-methods-in-hydrology/oclc/3240701

20. Intergovernmental Panel on Climate Change (IPCC), 2001. Houghton, J.T., Ding,Y., Griggs, D.J., Noguer, M., van der Linden, P.J., Dai, X., Maskell, K., Johnson, C.A., (Editors). Climate Change 2001: The Scientific Basis, Contribution of working Group I to Third Assessment Report of the Intergovernmental Panel on Climate Change, Cambridge University Press, Cambridge, United Kingdom.

https://www.ipcc.ch/site/assets/uploads/2018/03/WGI_TAR_full_report.pdf

21. Jasrotia, A.S., Kumar, R., Saraf, A.K., 2007. Delineation of groundwater recharge sites using integrated remote sensing and GIS in Jammu district, India, International Journal of Remote Sensing, Volume 28, Issue 22, 5019-5036.

22. Javed Mallick, Chander Kumar Singh, Hussein Al-Wadi, Mohd Ahmed, Atiqur Rahman, Satyanarayan Shashtri, Saumitra Mukherjee, 2015. Geospatial and Geostatistical approach for groundwater potential zone delineation, Hydrological Processes, Volume 29, Issue 3, 395-418. https://doi.org/10.1002/hyp.10153

23. Jaya Rami Reddy, P., 2001. A textbook of Hydrology, Third Edition, Laxmi Publications Private Limited, New Delhi.

24. Kamal Taheri, Milad Taheri, Mario Parise, 2016. Impact of intensive groundwater exploitation on an unprotected covered karst aquifer: a case study in Kermanshah Province, western Iran, Environmental Earth Sciences,75:1221, 1-16. DOI: 10.1007/s12665-016-5995-5.

25. Kanagaraj, G., Elango, L., Sridhar, S.G.D., Gowrisankar, G., 2018. Hydrogeochemical processes and influence of seawater intrusion in coastal aquifers south of Chennai, Tamil Nadu, India, Environmental Science and Pollution Research, 25, 8989-9011. https://doi.org/10.1007/s11356-017-0910-5

26. Korrakoch Taweesin, Uma Seeboonruang, Phayom Saraphirom, 2018. The Influence of Climate variability effects on groundwater time series in the lower Central Plains of Thailand, Water (Switzzerland), Volume 10, Issue 3, 1-23. https://doi.org/10.3390/w10030290 
27. Krishnamurthy, J., Venkatesa Kumar, N., Jayaraman, V., Manivel, M., 1996. An Approach to Demarcate Groundwater Potential Zones through Remote Sensing and GIS, International Journal of Remote Sensing, Volume, 17, Issue 10, 1867-1884. https://doi.org/10.1080/01431169608948744

28. Magesh, N., Chandrasekar, N., John Prince Soundranayagam, 2011. Morphometric evaluation of Papanasam and Manimuthar watersheds, parts of Western Ghats, Tirunelveli district, Tamil Nadu, India: a GIS approach, Environmental Earth Sciences, 64, 373-381. https://doi.org/10.1007/s12665-010-0860-4

29. Manjunathan, N., Thirukumaran, V., Thirumurugan, V., 2021. Identification of Groundwater Potential Zones using Time Series analysis and GIS applications in palar river basin, Tamil Nadu, India, NOVYI MIR Research Journal, Volume 6, Issue 4, 2021, 88-109.

DOI:16.10098.NMRJ.2021.V6I4.256342.1842,https://app.box.com/s/eswfjp6vxeihhwkx21b22xabbreddjdz

30. Mishra Ashok K., Vijay P. Singh, 2010. Drought modeling - A review, Journal of Hydrology, 403, 157-175.

31. Mohamad Aflatooni and Mehdi Mardaneh, 2011. Time series analysis of ground water table fluctuations due to temperature and rainfall change in Shiraz plain, International Journal of Water Resources and Environmental Engineering, Volume 3, Issue 9, 176-188.

https://academicjournals.org/journal/IJWREE/article-full-text-pdf/1344B0E54622

32. Nag, S.K., 2005. Application of lineament density and hydrogeomorphology to delineate groundwater potential zones of Baghmundi blocks in Purulia district, West Bengal, Journal of the Indian Society of Remote Sensing, 33, Article number 521. https://doi.org/10.1007/BF02990737

33. Narasimhan, T.N., 1990. Paleochannels of the Palar River West of Madras City: Possible implications for vertical movement, Journal of Geological Society of India, Volume 36 Issue 5, 471-474.

34. Pankaj K. Srivastava, Amit K. Bhattacharya, 2006. Groundwater assessment through an integrated approach using remote sensing, GIS and resistivity techniques: a case study from a hard rock terrain, International Journal of Remote Sensing, Volume 27, Issue 20, 4599-4620.

35. Pankratz Alan, 1983. Forecasting with univariate Box-Jenkins Models: Concepts and Cases, $1^{\text {st }}$ edition, Wiley Series in Probability and Statistics.

36. Prasenjit Mondal, Ajay Dalai, K., 2017. Sustainable Utilization of Natural Resources, $1^{\text {st }}$ edition, CRC press, Taylor and Francis Group, Social Science \& STEM Books.

37. Preeja, K.R., Sabu Joseph, Jobin Thomas, Vijith, H., 2011. Identification of Groundwater Potential Zones of a Tropical River Basin (Kerala, India) Using Remote Sensing and GIS Techniques, Journal of the Indian Society of Remote Sensing, 39, 83-94. https://doi.org/10.1007/s12524-011-0075-5

38. Ragunath, H.M., 1986. A text book of Hydrology, Wiley Eastern Limited, New Delhi.

39. Rajaveni, S.P., Brindha, K., Elango, L., 2017. Geological and Geomorphological controls on groundwater occurrence in hard rock region, Applied Water Science 7, 1377-1389. https://doi.org/10.1007/s13201-0150327-6

40. Ramasamy, S.M., Anbazhagan, S., 1997. Integrated terrain analysis in site selection for artificial recharge in Ayyar basin, Tamil Nadu, India, Reprinted from ESCAP Water Resources Journal, SER.C/190, 43-48.

41. Rasmi, M.R., Hema Achyuthan, Manoj Kumar Jaiswal, 2016. Middle to late Holocene paleochannels and migration of the Palar River, Tamil Nadu: Implications of neotectonic activity, Quaternary International, Elsevier Ltd and INQUA, 1-12. DOI: 10.1016/j.quaint.2016.05.002

https://doi.org/10.1016/j.quaint.2016.05.002

Page $12 / 22$ 
42. Seifu Kebede, 2013. Groundwater in Ethiopia, Features, numbers and opportunities, Heidelberg, Germany, Springer Hydrogeology. https://doi.org/10.1007/978-3-642-30391-3

43. Senthil Kumar, G.R., Shankar, K., 2014. Assessment of Groundwater Potential Zones Using GIS, Frontiers in Geosciences, Volume 2, Issue 1, 1-10.

44. Shah, T., 2005. Groundwater and human development: challenges and opportunities in livelihoods and environment, Water Science \& Technology, Volume 51, Issue 8, 27-37. https://doi.org/10.2166/wst.2005.0217

45. Sharma, 1995. Extrapolation for Time-Series and Cross-Sectional Data, Publisher Springer. URL:http://www.springer.com/business+\%26+management/business+for+professionals/book/

46. Singh, V.P., 1992. Elementary Hydrology, e-book, Englewood Cliffs, NJ: Prentice Hall, United State of America.

47. Subba Rao, N., 2006. Groundwater potential index in a crystalline terrain using remote sensing data, Environmental Geology 50, 1067-1076. https://doi.org/10.1007/s00254-006-0280-7

48. Tariq Mahgoub Mohamed and Abbasabd Allah Ibrahim, 2016. Time Series Analysis of Nyala Rainfall Using ARIMA Method, SUST Journal of Engineering and Computer Science (JECS), volume 17(1), 5-11.

49. Taylor, R.G., Scanlon, B., Doll, P., Rodell, M., Van Beek, R., Wada, Y., Konikow, L., 2013a. Groundwater and Climate Change, Nature Climate Change, Volume 3, Issue 4, 374-378.

50. Taylor, R.G., Todd, M.C., M.C., Kongola, L., Mauric, L., Nahozya, E., Sanga, H., MacDonald, A.M., $2013 b$. Evidence of dependence of Groundwater resource on extreme rainfall in the East Africa, Nature Climate Change, Volume 3, Issue 4, 322-330.

51. Thiessen, A.H., 1911. Precipitation Averages for Large Areas, Monthly Weather Review, Volume 39, Issue 7, 1082-1084. https://journals.ametsoc.org/view/journals/mwre/39/7/15200493_1911_39_1082b_pafla_2_0_co_2.xml?tab_body=abstract-display

52. Thirukumaran, V., Kumanan, C.J., Biswal, T.K., 2014. Geoinformatics Modeling of Groundwater Resource Mapping of Shear Zone Regions-A Case Study on Attur Valley, Tamil Nadu, India.

53. Thirumurugan, V., Thirukumaran, V., Sridharan, V., Manivannan, V., 2016. Morphometric analysis for geohydrological studies of upper Amaravathi basin using geo spatial technology, International Journal of Current Advanced Research, Volume 5, Issue 11, 1427-1436.

54. Thirumurugan, V., Thirukumaran, V., Sridharan, V., Manivannan, V., 2016. Arima modelling of water table fluctuations due to rainfall variations in Shanmuga Nadhi sub-basin of upper Amaravathi basin, Tamil Nadu, India, International Journal of Recent Scientific Research, Volume-7, Issue 11, 14149-14164.

55. Thomas Sabu Joseph, Thrivikram, K.P., George Abe, 2011. Morphometric analysis of the drainage system and its hydrological implications in the rain shadow regions, Kerala, India, Journal of Geographical Sciences, 21, Article number: 1077. https://doi.org/10.1007/s11442-011-0901-2

56. Tiwari, A., Rai, B., 1996. Hydromorphogeological Mapping for Groundwater Prospecting Using LandsatMSS Images - A Case Study of Part of Dhanbad District, Bihar Journal of the Indian Society of Remote Sensing, 24, 281-285. https://doi.org/10.1007/BF03026236

57. Vaidyanadhan, R., 1971. Evolution of the Drainage of Cauvery in South India, Journal of Geological Society of India, Volume 12, Issue 1, 14-25. 
58. Vanessa Madrucci, Fabio Taioli, Carlos Cesar de Araujo, 2008. Groundwater favourability map using GIS multicriteria data analysis on crystalline terrain, São Paulo State, Brazil, Journal of Hydrology, Volume 357, Issue 3, 153-173. https://doi.org/10.1016/j.jhydrol.2008.03.026

59. Vassan, D.T., 2002. Specific aquifer vulnerability assessment using Geographic Information System and modified drastic model, Ph.D Thesis, Department of Engineering, Anna University.

\section{Figures}

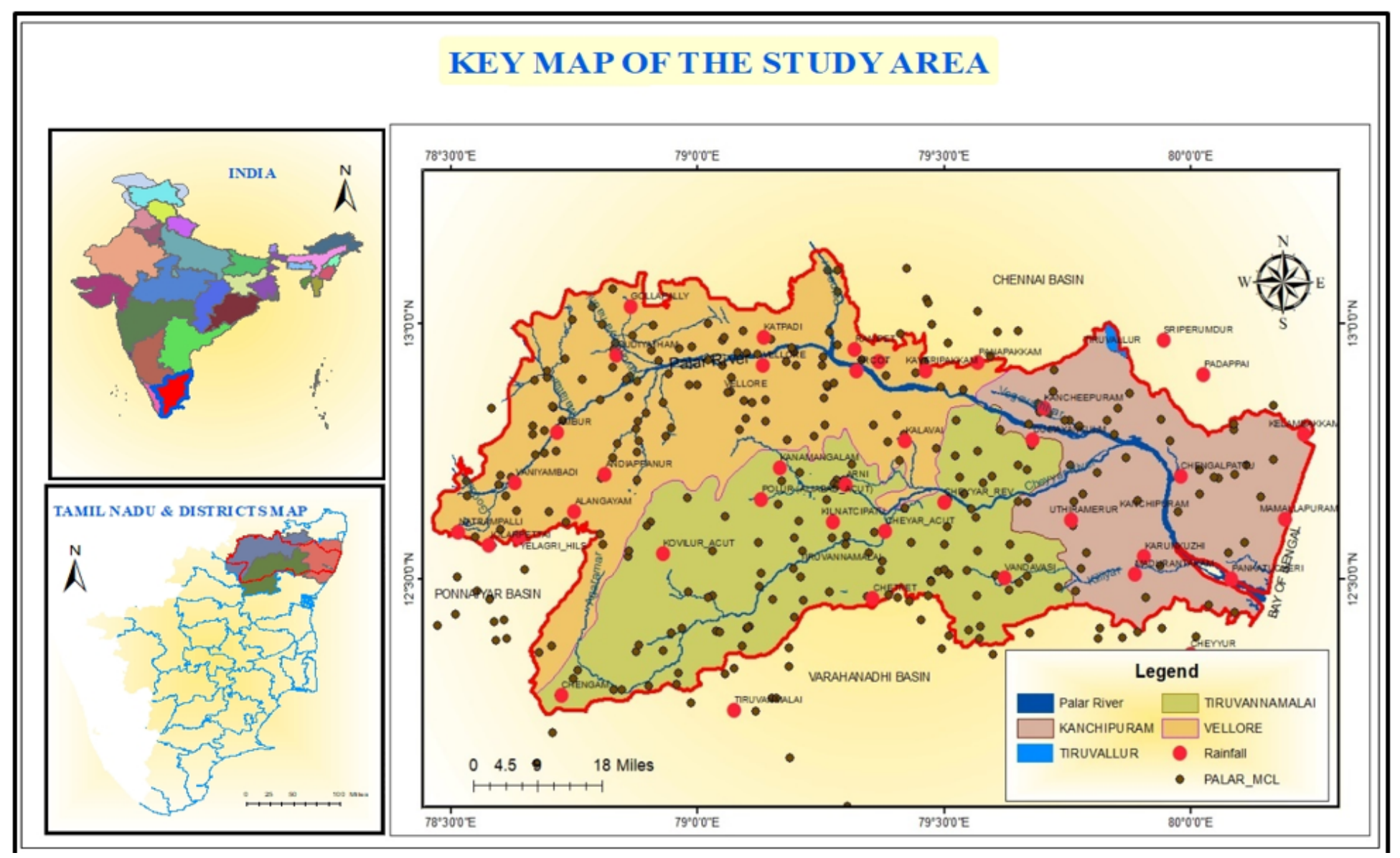

Figure 1

Key Map of the Study Area (Palar River Basin) 


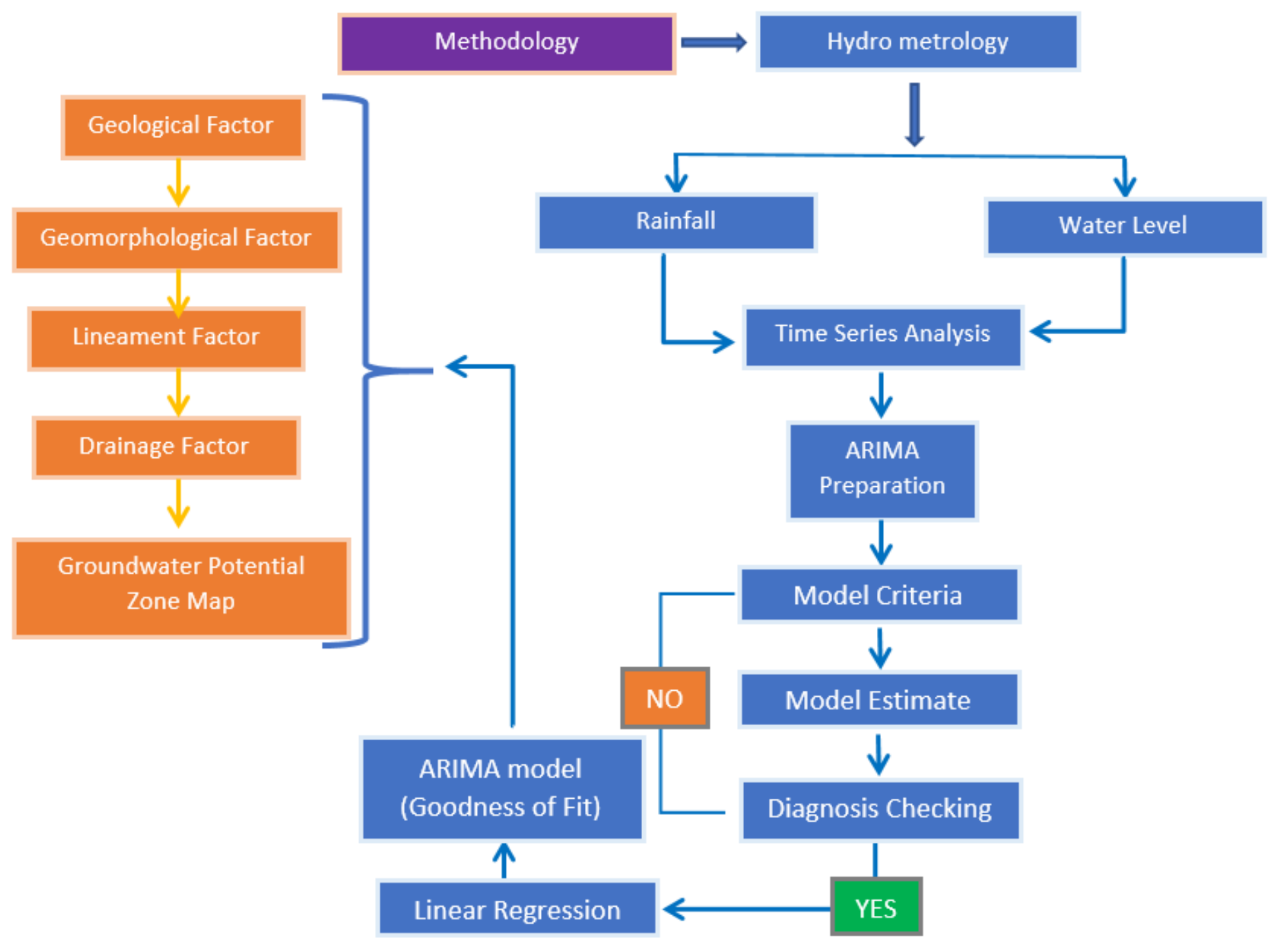

Figure 2

Methodology adopted for identification of groundwater potential zones 


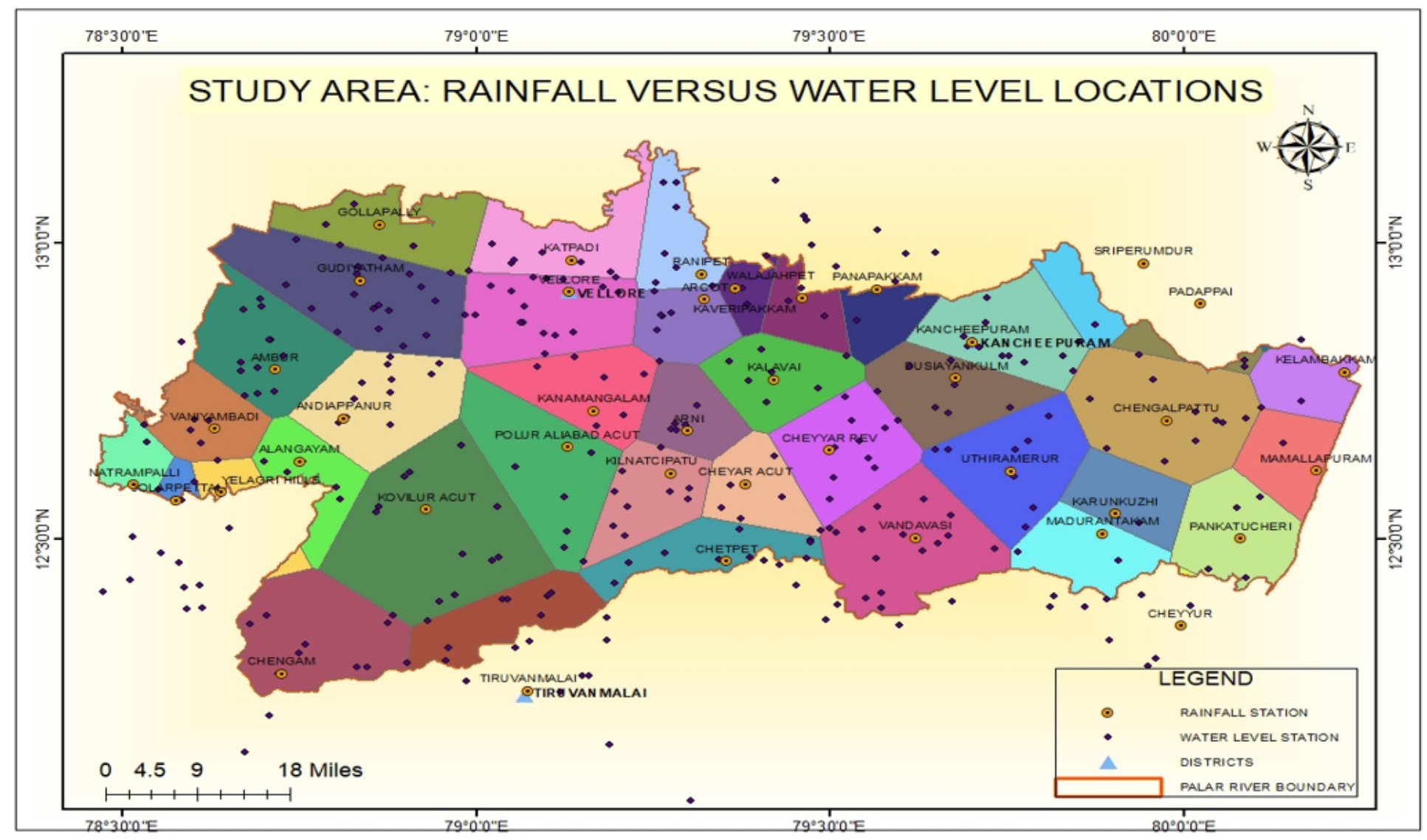

Figure 3

Theissen Polygon map of Palar River Basin 


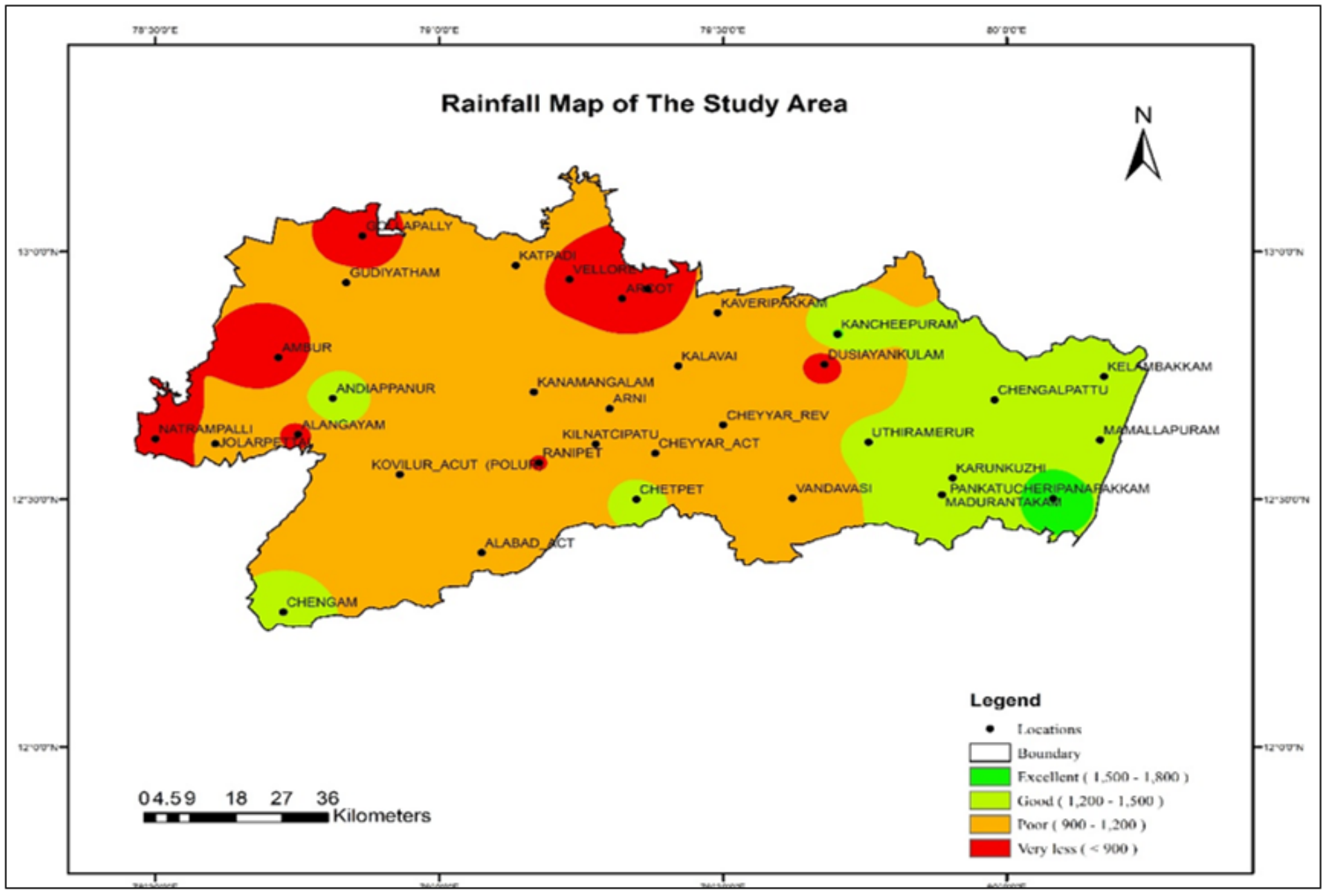

Figure 4

Rainfall map of Palar River Basin 


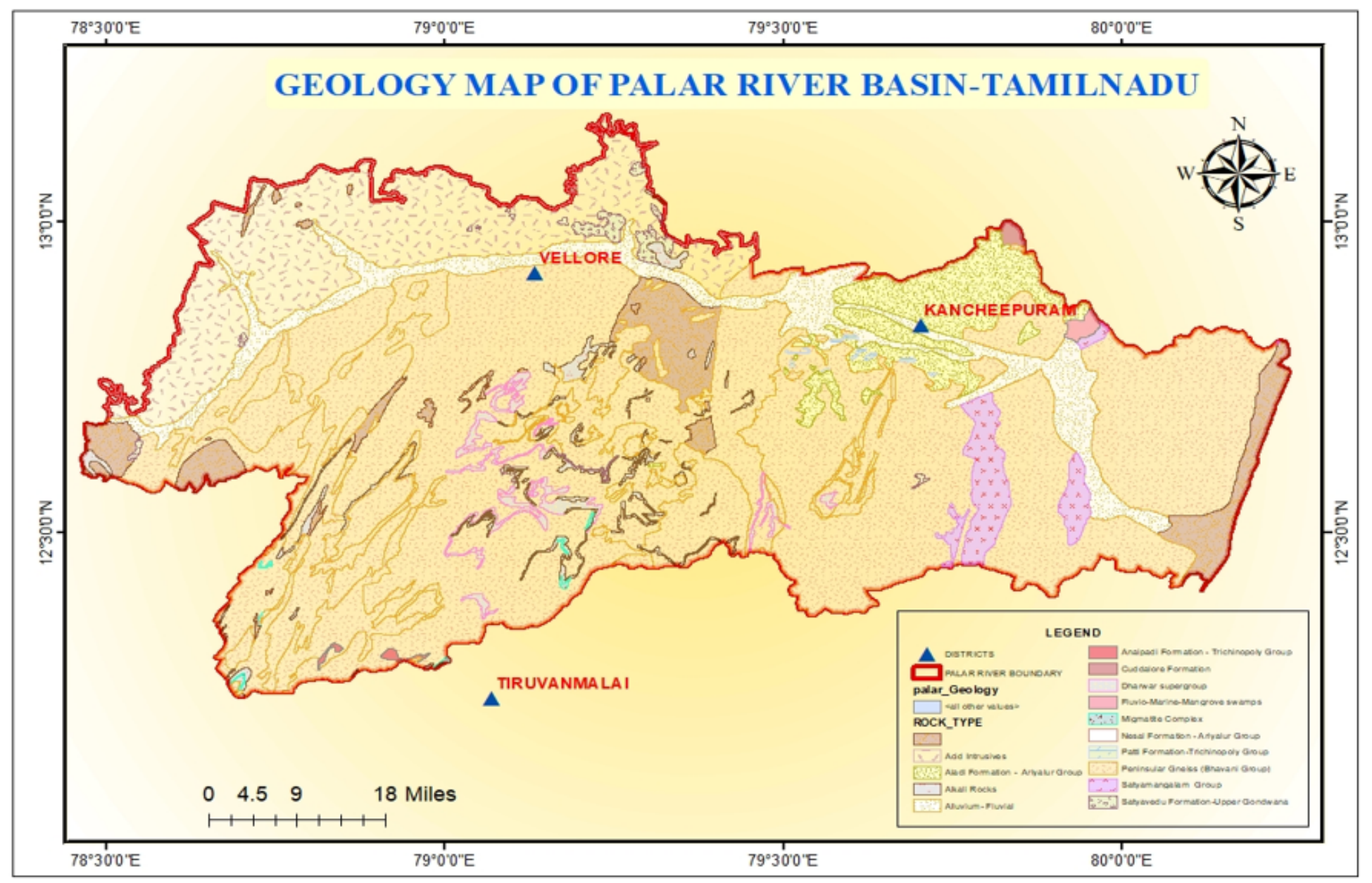

Figure 5

Geology map of Palar River Basin 


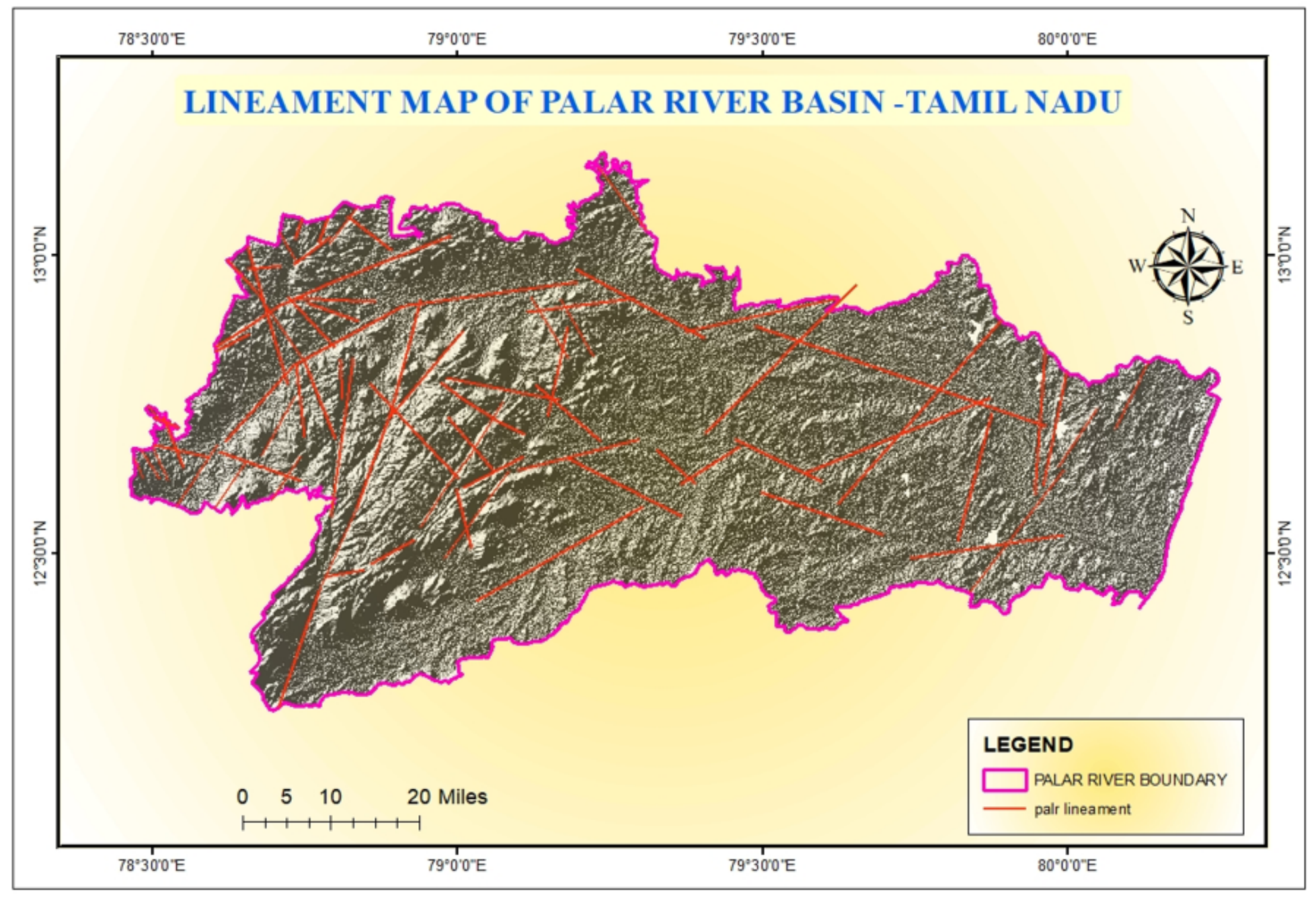

Figure 6

Lineament map of Palar River Basin 


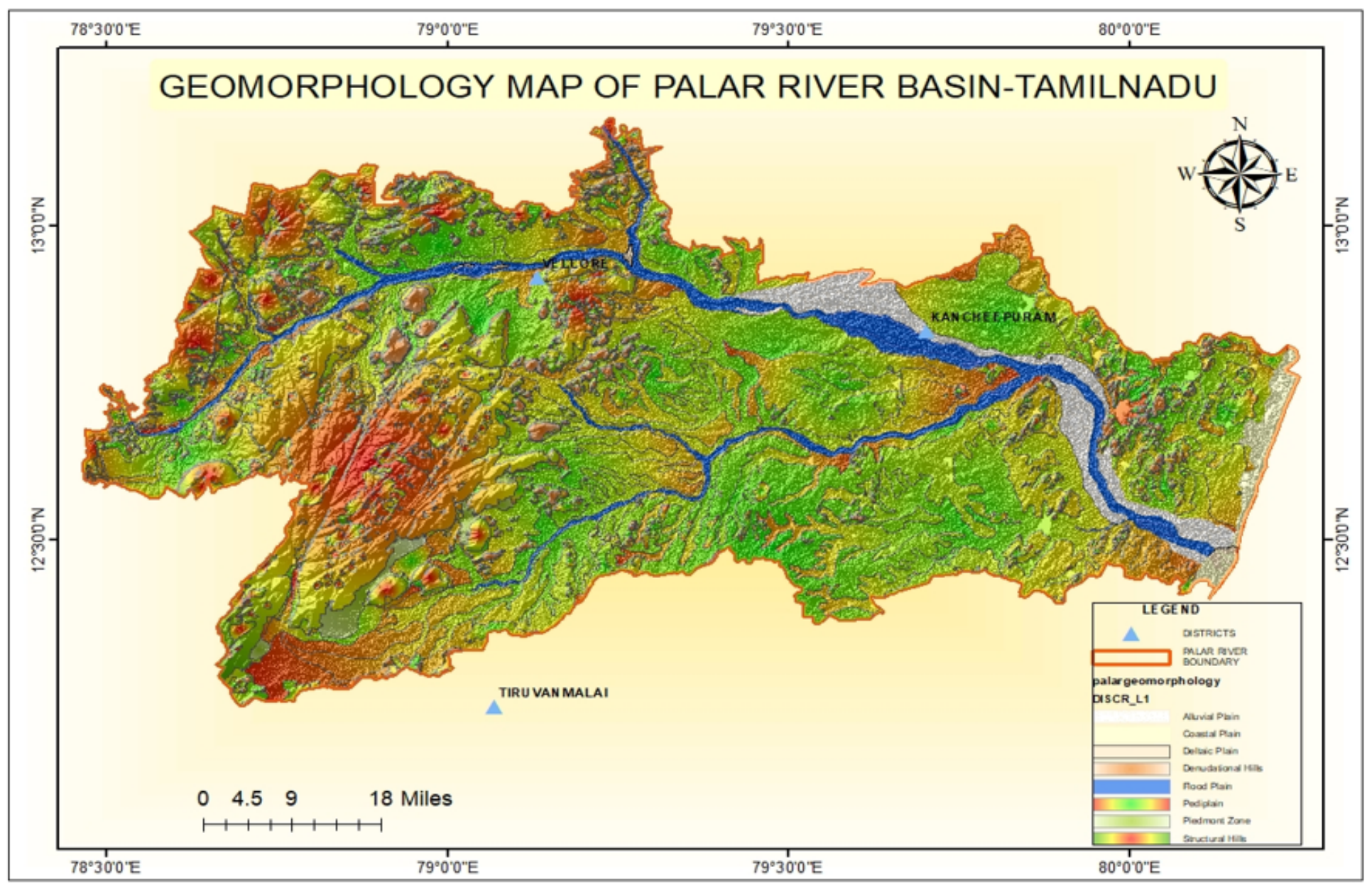

Figure 7

Geomorphology map of Palar River Basin 


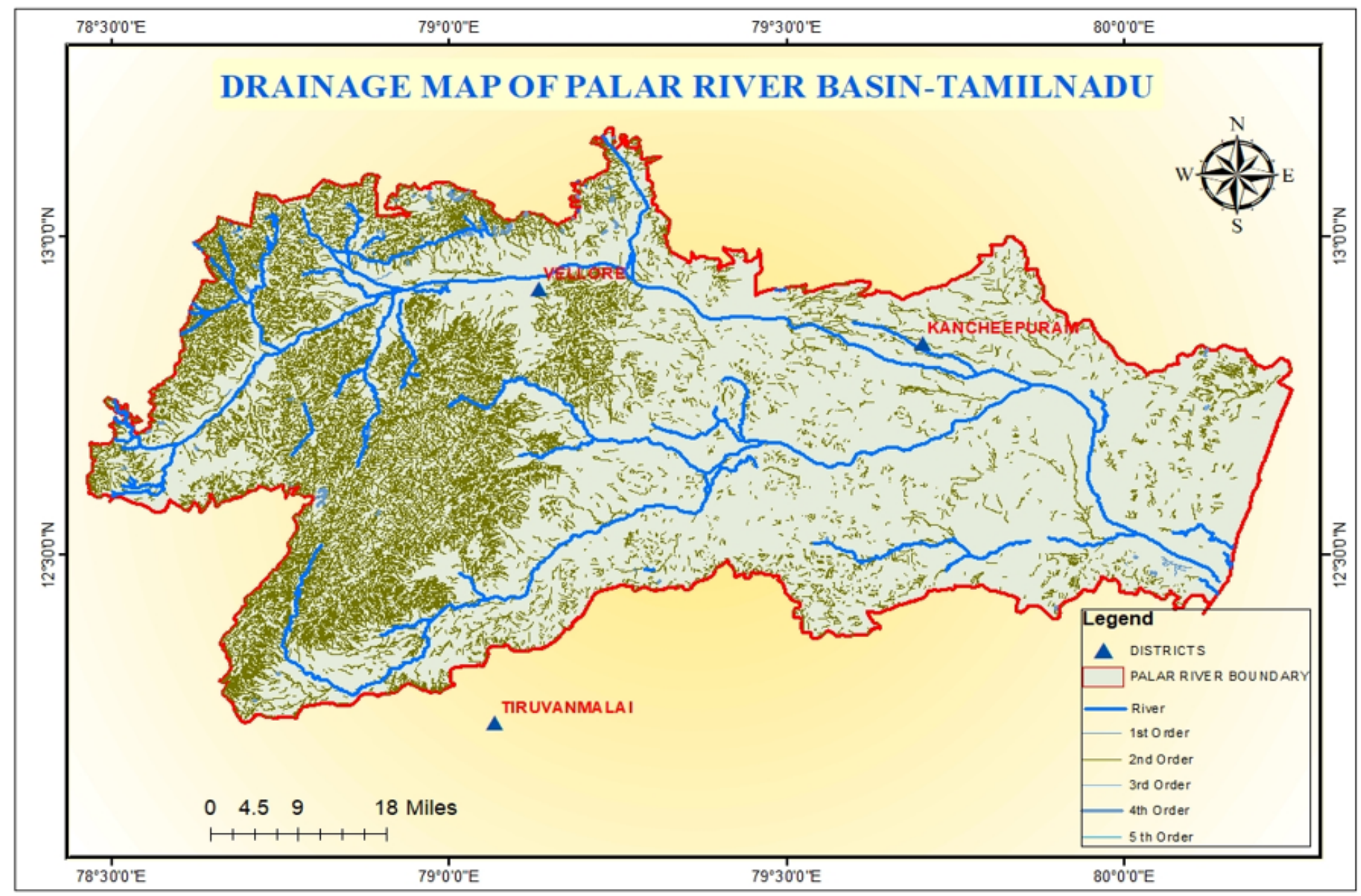

Figure 8

Drainage map of Palar River Basin 


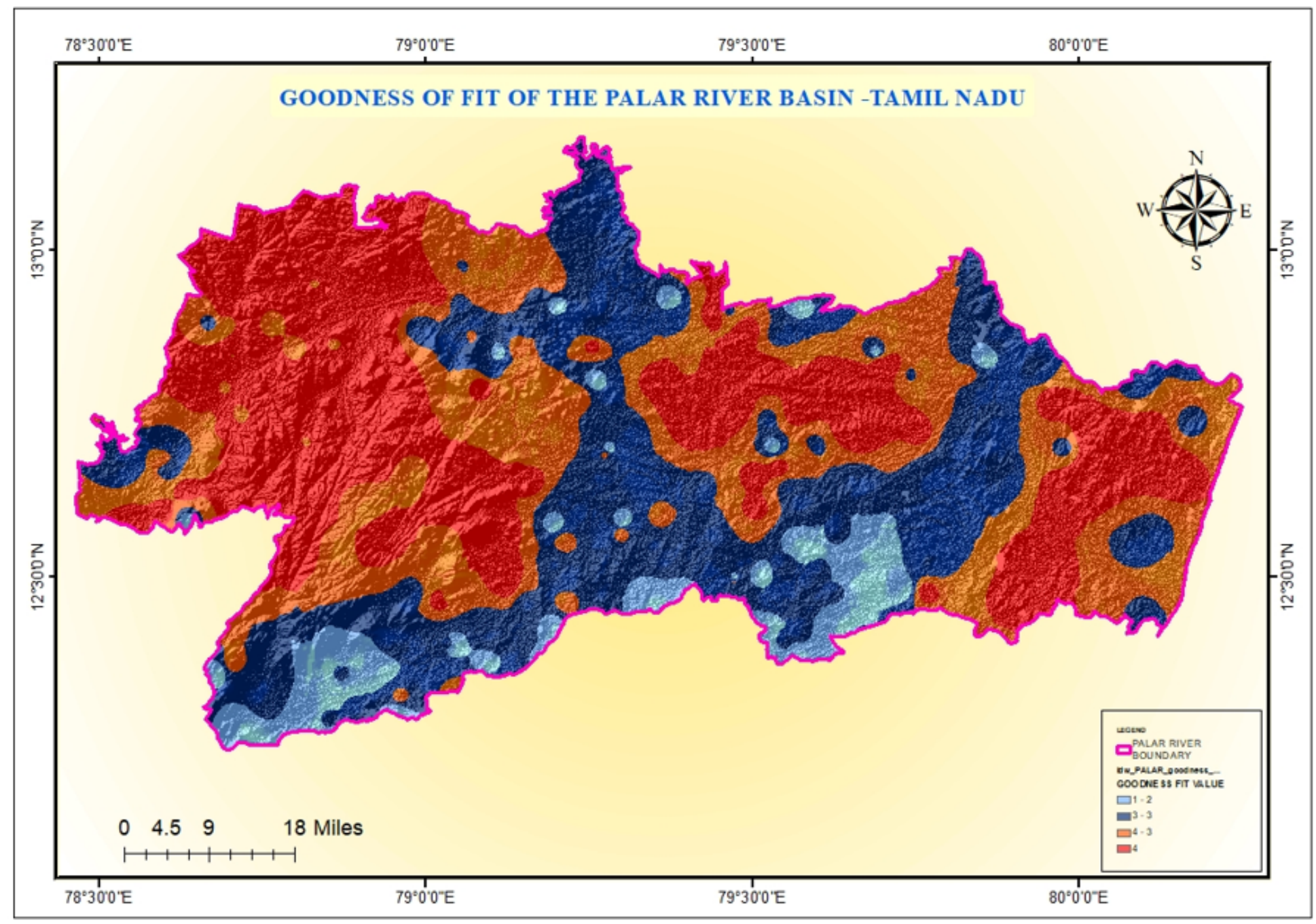

Figure 9

Groundwater Potential Zone map of Palar River Basin 